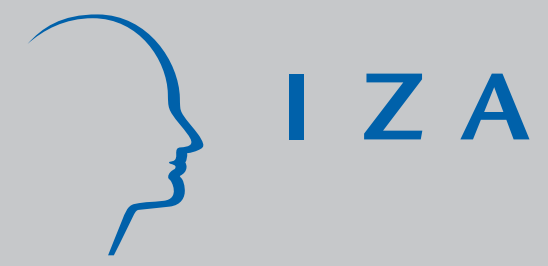

IZA DP No. 5668

The Role of Race and Birth Place in Welfare Usage among Comparable Women: Evidence from the U.S.

Ruth Uwaifo Oyelere

Maharouf Oyolola

April 2011

Forschungsinstitut zur Zukunft der Arbeit Institute for the Study of Labor 


\title{
The Role of Race and Birth Place in Welfare Usage among Comparable Women: Evidence from the U.S.
}

\author{
Ruth Uwaifo Oyelere \\ Georgia Institute of Technology \\ and IZA \\ Maharouf Oyolola \\ University of Vermont
}

\section{Discussion Paper No. 5668 \\ April 2011}

IZA

P.O. Box 7240

53072 Bonn

Germany

Phone: +49-228-3894-0

Fax: +49-228-3894-180

E-mail: iza@iza.org

Any opinions expressed here are those of the author(s) and not those of IZA. Research published in this series may include views on policy, but the institute itself takes no institutional policy positions.

The Institute for the Study of Labor (IZA) in Bonn is a local and virtual international research center and a place of communication between science, politics and business. IZA is an independent nonprofit organization supported by Deutsche Post Foundation. The center is associated with the University of Bonn and offers a stimulating research environment through its international network, workshops and conferences, data service, project support, research visits and doctoral program. IZA engages in (i) original and internationally competitive research in all fields of labor economics, (ii) development of policy concepts, and (iii) dissemination of research results and concepts to the interested public.

IZA Discussion Papers often represent preliminary work and are circulated to encourage discussion. Citation of such a paper should account for its provisional character. A revised version may be available directly from the author. 


\section{ABSTRACT \\ The Role of Race and Birth Place in Welfare Usage among Comparable Women: Evidence from the U.S. ${ }^{1}$}

There is evidence that women are more likely to live in poverty than men. Given the fact that the poor are more likely to use welfare, it becomes useful to consider welfare usage among women. A-priori welfare programs are set up in such a way that welfare usage should be based primarily on economic needs and health concerns. However, it is possible that an individual's experiences could affect their perception and preferences for using government assistance. In this scenario, differences in welfare usage will exist for individuals with similar characteristics but different experiences. We explore this possibility among women and investigate if race/ethnicity and birthplace still have a role to play in the decision to use welfare even after controlling for income, health and other demographic factors like employment. We find that race does not matter for welfare usage among comparable women. In addition, we do not find any significant differences in welfare usage among women based on birthplace - suggesting that comparable naturalized and native born women share similar preference for welfare. The only exception is women born in U.S territories. Our results suggest that among comparable women, women born in U.S territories seem to be more inclined to welfare usage in comparison to U.S born White women.

JEL Classification: J2, J10, J24, J38, I21, O12, O15

Keywords: $\quad$ welfare usage, women, immigrants, race, ethnicity, birth place, black, welfare, immigrant status

Corresponding author:

Ruth Uwaifo Oyelere

Georgia Institute of Technology

School of Economics

221 Bobby Dodd Way

Atlanta, GA 30332-0615

USA

E-mail: ruth.uwaifo@econ.gatech.edu

\footnotetext{
${ }^{1}$ The authors would especially like to thank Stephanie Seguino and Kwabena Gyimah-Brempong and for advice and useful comments. In addition, we thank participant of the Invisible Women Conference 2011 for comments. Of course, all remaining errors are ours. Data for this paper was derived from IPUMS. This is a working paper and comments are appreciated.
} 


\section{Introduction}

With the steadfast calls by congress-dominated Republicans to downsize major federally-funded programs, there are concerns that some welfare programs might be at risk of being cut. Given many more welfare recipients are women versus men, an analysis focused on women's preference for welfare and usage is useful. In the early 90s there were several studies that suggested abuse of the welfare system. In reaction to these findings and public perception that individuals, specifically immigrants and minorities, were abusing the U.S. welfare system, Congress decided to tighten the grips by passing the Personal Responsibility and Work Opportunity Reconciliation Act (PRWORA) in 1996. The legislation ended welfare as an entitlement program, restricted the eligibility of immigrants to various programs, and provided stricter conditions for eligibility for Americans. Post welfare reform, the share of the population on welfare shrunk considerably as many past welfare recipients were forced to seek jobs (Greenwell 1998). However, recent studies suggest that significant negative effect of the welfare reform on the poor, especially poor women (Carnochan et al, 2002). They note that the vast majority of these individuals are still living below the poverty line and thus at risk of going back into the system. Though there is evidence in the literature that immigrants and minority racial groups use welfare more than citizens and Whites respectively [Borjas(1994, 1999; Borjas \& Hilton, 1996; Blau,1984; Hansen\& Lofstrom, 2003], the relevant question to ask is if immigrants or minorities have a higher preference for welfare than Whites. This is because a higher use of welfare by one group over the other may just reflect the differences in income or employability across these groups. A priori there is no reason to expect differential preference for welfare across race. This is important because welfare eligibility is determined on needs basis; hence usage should be driven by these criteria. However, given past research that seems to suggest a public perception of preference for welfare for most minorities and immigrants, and the fact that some attribute poverty and welfare dependency of welfare recipients to their own lack of drive and attitude towards employment ( Gillen 1999, Davis \& Hagen, 1996; Hunt, 1996; Smith \& Stone, 1989, Greenwell and Leibowitz (1998).), it becomes useful to investigate if a preference for welfare exists along birthplace and racial lines for women.

Although the existing literature on welfare programs has widely discussed the impact of the reform on poverty, marriage and other socioeconomic indicators ${ }^{2}$, it has, however, failed to discuss if there is racial preference in its usage-despite widespread public perception (Kellstedt, 2003). Only few papers have

\footnotetext{
${ }^{2}$ For example Lower-Basch, 2000, Bitler, Gelbach and Hoynes (2002), Greenwell and Leibowitz
} (1998), Carnochan et al, 2002. 
focused on preference for welfare usage across groups in the U.S. For example, Oyelere and Oyolola (2009) investigate differences in welfare by birthplace and citizenship status. We follow along these lines in our analysis of women's welfare usage. Our two main questions of interest are: (i) Is there any racial/ethnic differences in welfare usage among comparable women? (ii) Does experience/exposure as captured by birthplace affect welfare usage among comparable women? By comparable women, we are referring to women that should have similar levels of welfare usage given their characteristics. The characteristics we are referring to here are the factors that traditionally explain welfare usage .

Our initial results suggest that race matters for welfare usage. However, this result is not robust and through further investigation we are able to show that though some specific subgroups of women are more likely to use welfare than White women, race is really not important for welfare usage among women. We also find that for most comparable women, birthplace does not matter for welfare usage. The only exception being women from U.S territories. We find that comparable women born in U.S territories are more likely to use welfare than women born in the U.S.

This paper contributes to the literature by highlighting that among comparable women, there is no preference for welfare usage along racial lines. Second among comparable natives and immigrant women, there is no preference for welfare. Finally, individuals experience or background as captured by birthplace is not important for predicting welfare usage among most women.

The remainder of the paper is as follows. In section 2 we highlight the data and provide some descriptive statistics. In section 3 we outline our empirical strategy and in section 4 we present our results. We conclude in the last section.

\section{Data}

The data we use comes from the Current Population Survey (CPS). We specifically make use of data for Women from 1996-2008 . We derive multi-stage stratified samples of the CPS from Integrated Public Use Microdata Series, Current Population Survey (IPUMS-CPS).3 We select the period of 19962008 for our analysis because the question on immigrants birthplace continent was only introduced in 1994 and fully defined from 1995. Specifically, the breakdown of birth place continent was limited in the 1994 survey, for example, we cannot differentiate immigrants from Africa from immigrants from

\footnotetext{
${ }^{3}$ Steven Ruggles, J. Trent Alexander, Katie Genadek, Ronald Goeken, Matthew B. Schroeder, and Matthew Sobek. Integrated Public Use Microdata Series: Version 5.0 [Machine-readable database]. Minneapolis: University of Minnesota, 2010
} 
most parts of Asia. In addition, we assume controlling for health could be important in predicting welfare usage and this variable is only available from 1996 onwards. One of the advantages of using the CPS via IPUMS is that it makes cross-time comparisons using the March CPS data more feasible as variables in IPUMS-CPS are coded identically or "harmonized” for 1962 to 2008.

Table 1 provides a summary of different types of government assistance by race/ethnicity and immigration status. This table highlights what has been documented in the past literature on welfare usage by race. Women from most minorities (Hispanic Black, Native American) have higher participation rates in welfare programs than White and Asian women. Though the results in this table highlight differences in usage rates across ethnicity, it does not say anything about preference for use. Differences across race could be linked to differences across need. For example women from minority groups tend to be poorer and unemployed, so we expect this could lead to higher welfare usage. Education is one factor that is generally believed should reduce the probability of being poor and welfare usage.

Table 1: Different forms of Welfare Usage by Women across race and nativity (1994-2008)

\begin{tabular}{|c|c|c|c|c|c|c|c|c|c|c|}
\hline & \multicolumn{2}{|c|}{ Food stamp } & \multicolumn{2}{|c|}{ Public housing } & \multicolumn{2}{|c|}{$\begin{array}{l}\text { Heat } \\
\text { Subsidy }\end{array}$} & \multicolumn{2}{|c|}{$\begin{array}{l}\text { Welfare } \\
\text { Income }\end{array}$} & \multicolumn{2}{|c|}{$\begin{array}{l}\text { Any form of } \\
\text { welfare }\end{array}$} \\
\hline & $\mathrm{N}$ & I & $\mathrm{N}$ & I & $\mathrm{N}$ & I & $\mathrm{N}$ & I & $\mathrm{N}$ & I \\
\hline Blacks & $\begin{array}{l}0.230 \\
(0.42)\end{array}$ & $\begin{array}{l}0.11 \\
(0.31)\end{array}$ & $\begin{array}{l}0.126 \\
(0.33)\end{array}$ & $\begin{array}{l}0.06 \\
(0.24)\end{array}$ & $\begin{array}{l}0.063 \\
(0.24)\end{array}$ & $\begin{array}{l}0.027 \\
(0.16)\end{array}$ & $\begin{array}{l}0.059 \\
(0.23)\end{array}$ & $\begin{array}{l}0.037 \\
(0.18)\end{array}$ & $\begin{array}{l}0.305 \\
(0.46)\end{array}$ & $\begin{array}{l}0.1644 \\
(0.37)\end{array}$ \\
\hline Whites & $\begin{array}{l}0.069 \\
(0.25)\end{array}$ & $\begin{array}{l}0.099 \\
(0.29)\end{array}$ & $\begin{array}{l}0.048 \\
(0.21)\end{array}$ & $\begin{array}{l}0.046 \\
(0.21)\end{array}$ & $\begin{array}{l}0.028 \\
(0.16)\end{array}$ & $\begin{array}{l}0.02 \\
(0.14)\end{array}$ & $\begin{array}{l}0.015 \\
(0.12)\end{array}$ & $\begin{array}{l}0.027 \\
(0.16)\end{array}$ & $\begin{array}{l}0.089 \\
(0.29)\end{array}$ & $\begin{array}{l}0.093 \\
(0.29)\end{array}$ \\
\hline Asians & $\begin{array}{l}0.067 \\
(0.25)\end{array}$ & $\begin{array}{l}0.04 \\
(0.21)\end{array}$ & $\begin{array}{l}0.053 \\
(0.22)\end{array}$ & $\begin{array}{l}0.034 \\
(0.54)\end{array}$ & $\begin{array}{l}0.014 \\
(0.11)\end{array}$ & $\begin{array}{l}0.012 \\
(0.11)\end{array}$ & $\begin{array}{l}0.016 \\
(0.12)\end{array}$ & $\begin{array}{l}0.012 \\
(0.10)\end{array}$ & $\begin{array}{l}0.098 \\
(0.30)\end{array}$ & $\begin{array}{l}0.006 \\
(0.07)\end{array}$ \\
\hline $\begin{array}{l}\text { Native } \\
\text { American }\end{array}$ & $\begin{array}{l}0.243 \\
(0.43)\end{array}$ & $\begin{array}{l}0.073 \\
(0.26)\end{array}$ & $\begin{array}{l}0.092 \\
(0.29)\end{array}$ & $\begin{array}{l}0.18 \\
(0.21)\end{array}$ & $\begin{array}{l}0.144 \\
(0.35)\end{array}$ & $\begin{array}{l}0.027 \\
(0.16)\end{array}$ & $\begin{array}{l}0.052 \\
(0.22)\end{array}$ & $\begin{array}{l}0.011 \\
(0.12)\end{array}$ & $\begin{array}{l}0.351 \\
(0.48)\end{array}$ & $\begin{array}{l}0.103 \\
(0.30)\end{array}$ \\
\hline Hispanic & $\begin{array}{l}0.17 \\
(0.38)\end{array}$ & $\begin{array}{l}0.13 \\
(0.34)\end{array}$ & $\begin{array}{l}0.069 \\
(0.25)\end{array}$ & $\begin{array}{l}0.033 \\
(0.18)\end{array}$ & $\begin{array}{l}0.042 \\
(0.20)\end{array}$ & $\begin{array}{l}0.02 \\
(0.14)\end{array}$ & $\begin{array}{l}0.04 \\
(0.19)\end{array}$ & $\begin{array}{l}0.038 \\
(0.19)\end{array}$ & $\begin{array}{l}0.207 \\
(0.41)\end{array}$ & $\begin{array}{l}0.171 \\
(0.38)\end{array}$ \\
\hline
\end{tabular}

Note N-Native Born I--Immigrant, Standard deviation in parenthesis.

In Table 2 we examine if the proportion of those using welfare drops significantly with education level and also whether there are similarities across race at each level of education. We find that at all levels of education, native minority women apart from Asians have a higher proportion on welfare than White native women. Again these results do not inform us about preferences across race/ethnicity. Women who are at similar levels of education could have different employment status and income that would affect their need for welfare. In our econometric analysis we will test for racial differences in preference for welfare usage by considering welfare usage among comparable individuals. 
Table 2: Educational attainment of women welfare users by select race and nativity

\begin{tabular}{|c|c|c|c|c|c|c|c|c|}
\hline & \multicolumn{2}{|c|}{ Blacks } & \multicolumn{2}{|c|}{ Whites } & \multicolumn{2}{|c|}{ Asians } & \multicolumn{2}{|c|}{ Hispanic } \\
\hline & $\mathbf{N}$ & I & $\mathbf{N}$ & I & $\mathbf{N}$ & I & $\mathbf{N}$ & I \\
\hline E1 & $0.45(0.50)$ & $0.28(0.45)$ & $0.17(0.38)$ & $\odot .19(0.39)$ & $0.16(0.36)$ & $0.24(0.43)$ & $0.33(0.47)$ & $0.22(0.42)$ \\
\hline E2 & $0.28(0.45)$ & $0.16(0.36)$ & $\odot . \odot 9(\odot .28)$ & $\odot .09(0.28)$ & $0.10(0.30)$ & $\odot .09(0.29)$ & $0.17(0.37)$ & $0.13(0.34)$ \\
\hline E3 & $0.18(0.39)$ & $\odot .088(0.28)$ & $0.055(023)$ & $0.05(0.225)$ & $0.059(0.24)$ & $0.052(0.22)$ & $0.010(0.30)$ & $0.012(0.32)$ \\
\hline E4 & $0.074(0.26)$ & $0.066(0.25)$ & $0.02(0.14)$ & $0.055(0.23)$ & $0.022(0.15)$ & $0.028(0.17)$ & $0.046(0.21)$ & $\odot .08 \odot(\odot .27)$ \\
\hline E5 & $0.036(0.19)$ & $0.034(0.18)$ & $0.011(0.10)$ & $\odot .039(0.19)$ & $0.014(0.12)$ & $0.015(0.12)$ & $0.023(0.15)$ & $\odot . \odot 49(\odot .22)$ \\
\hline
\end{tabular}

Note: (i) standard deviations are in parentheses

(ii) $\mathrm{N}=$ natives (Non naturalized citizens) and $\mathrm{I}=\mathrm{immigrants}$

(iii) E1=k-12 ${ }^{\text {th }}$ grade; E2=high school diploma; E3=associate degree; E4= bachelor

Degree; E5= masters, Ph.D. and professionals.

\section{Empirical Strategy}

To answer our questions of interest, we estimate equation 1 assuming a probit model ${ }^{4}$.

$\operatorname{Pr} o b(W=1)=\Phi\left(\alpha_{0}+\alpha_{1} \Omega+\alpha_{2} Z+\alpha_{3} \omega+\sum_{i} \Psi_{i} R_{i}\right)$

Where $\Omega$ is a matrix of traditional factors that impact the probability of welfare usage. ${ }^{5}$ The dependent variable $\mathrm{W}$ is a binary indicator that takes on a value of 1 if an individual is on some form of welfare and a value of 0 if the individual is not. The variable $\mathrm{W}$ is a comprehensive measure of any form of government assistance. $\mathrm{W}=1$ if the individual uses one or more of these welfare programs: food stamps, supplemental security income (SSI), government subsidized rent, government subsidized heating or receiving any income during the previous calendar year from various public assistance programs commonly referred to as “welfare”. $\Phi($.$) in equation (1) indicates the standard normal$ distribution. Variables included in the matrix $\Omega$ are traditional predictors of welfare usage, such as education, number of children, size of the family, marital status, immigration status, employment status

\footnotetext{
${ }^{4}$ We choose a probit model for our analysis. However, our results do not change if we assume a logit or linear probability model.

${ }^{5}$ by traditional factors we imply, economic and demographic factors that have been used to predict welfare usage.
} 
and for immigrants- years in the U.S. ${ }^{6} \mathrm{Z}$ is a matrix of dummy variables including year and state dummies. $\omega$ represents income, which is an important predictor of welfare usage. $\mathrm{R}$ is the matrix of the variables we are primarily interested in. The R matrix can have different dummy variables depending on the model we are testing. In our first model, our R matrix consists of dummy variables based on Race/Ethnicity. We divide the sample into White (non-Hispanic), Hispanic, Black, Asian, Native American, Mixed Race and Others. The others category captures those who did not indicate a race choice before 2002 because of the lack of an option of mixed race. From 2003 the options for mixed race where introduced and the category other was scrapped.

In our second model, we divide the R matrix based on birthplace . The categories for birth place are as follows: born in the U.S., born in U.S. protectorates, born in other North America (not U.S.), born in Central American and the Caribbean, born in South America, born in Europe, born in Asia, born in Africa, born in Oceania and finally the group 'others'. The group 'others' are those who did not choose or indicate a place of birth. Though the linear probability specification of the binary choice model provides ease of interpretation, we choose a probit model over it. This is because in the linear model, unless restrictions are placed on estimates, coefficients can imply probabilities outside the unit interval. We focus on the marginal effects from the probit model estimation. For the dummy variables, these marginal effects estimates capture the probability of being on welfare for a particular group relative to the baseline group.

To answer our first question, we initially estimate equation 1 and test for significant differences in the estimates of the probability of being on welfare for the different race/ethnic groups. We estimate different variations of the model in an attempt to identify carefully any differences across racial groups in women's welfare usage. To answer the second question, we estimate equation 1 with a new R matrix based on place of birth. We test for differences in the probability of being on welfare based on women's place of birth. Finally to ensure the robustness of our earlier results for our first question, we create an interaction dummy for race and birthplace and test for significant differences across these dummies. Our base group is White women born in the U.S.. Testing the model this way helps us address the question of whether it is really race or birthplace per se that matters for welfare usage or if these variables could be proxying for some other important factor for women.

\footnotetext{
${ }^{6}$ We are assuming that preference for marriage, employment and number of children are distributed similarly across race and do not proxy for welfare preference.
} 


\section{Results}

Table 3 summarizes our results of estimating equation 1. We test our first hypothesis using the estimates summarized in Table 3. In column (1) we look at all women in the sample. We control for income, employment status, marital status, family size, number of children, state fixed effects, health status and education. Focusing on our racial/ethnic dummies, the results in column (1) suggest that even after controlling for what should typically predict welfare usage, there are racial differences in welfare usage. The base group is Whites and these results suggest that all other women use welfare more than White women. Asian, Mixed race and Hispanic women seem to use welfare more than White women but not as much as Black women and Native American Women. Black Women have a 9\% higher probability of welfare usage than White women. This finding does not show that minorities have a preference for welfare usage because any analysis on the whole sample contains individuals who are not eligible for welfare. Given preference for welfare usage is not revealed for noneligible women, results in column (1) cannot reveal welfare usage preferences. In column (2) we consider only U.S citizens. For this group of women, preference for welfare is revealed. Our results are similar to those in column (1) though higher for Hispanics and lower for Blacks. This result suggests a slight higher preference for welfare use for women from minority groups than White women. U.S citizens consists of Native born and Naturalized citizens. It is possible to argue that evaluating welfare usage for both types of U.S citizens together might be slightly problematic because of possible differential distribution of information among native born versus naturalized citizens. Also there is the common argument of selectivity with immigrants and more so for those immigrants who choose to become American citizens. To avoid this minor issue serving as a confounding factors in our analysis, in column (4) and (5) we consider naturalized citizens and native born Americans separately. In column (3) we focus solely on immigrant women. However, this analysis is plagued with the same problem of preference revelation characterized by the analysis summarized in column one. This is because only naturalized immigrants and native born are fully eligible for welfare in all states. For immigrants who hold green card holders, eligibility is more heterogeneous. Post PRWORA many new green card holders were no longer eligible for welfare and eligibility of other green card holders varied across states. The results in column (4) suggest that even if we consider native born solely, racial differences in preference for welfare among women persists for most ethnic groups. Interestingly, the likelihood of welfare usage in comparison to White women does not change significantly across most races. The only exception is Asian women. Our results suggest that native born Asian women use welfare at the same rate as native born White 
women, meaning comparable Asian and White women exhibit identical preferences for welfare. In contrast, comparable Blacks, Hispanics and Native Americans seem to prefer welfare usage. If we look at column (5) and focus on naturalized immigrants we notice a similar trend.

\section{Table 3 Probability of Welfare Usage among Women}

\begin{tabular}{|c|c|c|c|c|c|}
\hline Variable & $\begin{array}{l}\text { All } \\
\qquad \begin{array}{l}d F / d x \\
(1)\end{array}\end{array}$ & $\begin{array}{l}\text { Citizens } \\
\mathrm{dF} / \mathrm{dx} \\
(2)\end{array}$ & $\begin{array}{c}\text { Immigrant } \\
\mathrm{dF} / \mathrm{dx} \\
\text { (3) }\end{array}$ & $\begin{array}{l}\text { U.S born } \\
\mathrm{dF} / \mathrm{dx} \\
(4)\end{array}$ & $\begin{array}{l}\text { Naturalized } \\
\mathrm{dF} / \mathrm{dx} \\
(5)\end{array}$ \\
\hline Hispanic & $\begin{array}{l}0.039 * \\
(0.001)\end{array}$ & $\begin{array}{r}0.047^{*} \\
(0.0011)\end{array}$ & $\begin{array}{l}0.029 * \\
(0.003)\end{array}$ & $\begin{array}{l}0.050 * \\
(0.001)\end{array}$ & $\begin{array}{l}0.036^{*} \\
(0.003)\end{array}$ \\
\hline Black & $\begin{array}{l}0.090 * \\
(0.002)\end{array}$ & $\begin{array}{l}0.088^{*} \\
(0.002)\end{array}$ & $\begin{array}{l}0.031 * \\
(0.005)\end{array}$ & $\begin{array}{l}0.088^{*} \\
(0.002)\end{array}$ & $\begin{array}{l}0.022^{*} \\
(0.005)\end{array}$ \\
\hline Native American & $\begin{array}{l}0.078^{*} \\
(0.004)\end{array}$ & $\begin{array}{l}0.075^{*} \\
(0.004)\end{array}$ & $\begin{array}{r}-0.011 \\
(0.016)\end{array}$ & $\begin{array}{l}0.074 * \\
(0.004)\end{array}$ & $\begin{array}{r}0.001 \\
(0.019)\end{array}$ \\
\hline Asian & $\begin{array}{r}0.0208^{*} \\
(0.002)\end{array}$ & $\begin{array}{l}0.015^{*} \\
(0.002)\end{array}$ & $\begin{array}{l}0.009 * \\
(0.003)\end{array}$ & $\begin{array}{r}0.003 \\
(0.003)\end{array}$ & $\begin{array}{l}0.010^{*} \\
(0.003)\end{array}$ \\
\hline Mixed & $\begin{array}{l}0.037^{*} \\
(0.004)\end{array}$ & $\begin{array}{l}0.035 * \\
(0.003)\end{array}$ & $\begin{array}{l}-0.017^{*} \\
(0.018)\end{array}$ & $\begin{array}{l}0.034 * \\
(0.003)\end{array}$ & $\begin{array}{r}0.004 \\
(0.021)\end{array}$ \\
\hline married spouse & & & & & \\
\hline absent & $\begin{array}{r}0.107^{*} \\
(0.005)^{*}\end{array}$ & $\begin{array}{l}0.114^{*} \\
(0.005)\end{array}$ & $\begin{array}{l}0.083^{*} \\
(0.008)\end{array}$ & $\begin{array}{l}0.115^{*} \\
(0.006)\end{array}$ & $\begin{array}{l}0.104^{*} \\
(0.015)\end{array}$ \\
\hline Separated & $\begin{array}{l}0.195^{*} \\
(0.004)\end{array}$ & $\begin{array}{l}0.190 * \\
(0.004)\end{array}$ & $\begin{array}{l}0.195^{*} \\
(0.008)\end{array}$ & $\begin{array}{l}0.191^{*} \\
(0.005)\end{array}$ & $\begin{array}{c}0.158^{*} \\
(0.013)\end{array}$ \\
\hline Divorced & $\begin{array}{l}0.145^{*} \\
(0.002)\end{array}$ & $\begin{array}{l}0.138^{*} \\
(0.002)\end{array}$ & $\begin{array}{l}0.135^{*} \\
(0.006)\end{array}$ & $\begin{array}{l}0.139 * \\
(0.002)\end{array}$ & $\begin{array}{c}0.109 * \\
(0.007)\end{array}$ \\
\hline Widowed & $\begin{array}{l}0.081 * \\
(0.002)\end{array}$ & $\begin{array}{l}0.075^{*} \\
(0.002)\end{array}$ & $\begin{array}{l}0.092^{*} \\
(0.005)\end{array}$ & $\begin{array}{l}0.075^{*} \\
(0.002)\end{array}$ & $\begin{array}{l}0.067^{*} \\
(0.006)\end{array}$ \\
\hline Single & $\begin{array}{c}0.097^{*} \\
(0.002)\end{array}$ & $\begin{array}{c}0.093^{*} \\
(0.002)\end{array}$ & $\begin{array}{c}0.109 * \\
(0.004)\end{array}$ & $\begin{array}{r}0.09 * \\
(0.002)\end{array}$ & $\begin{array}{l}0.114^{*} \\
(0.007)\end{array}$ \\
\hline age & $\begin{array}{l}-0.0007^{*} \\
2.43 E-05\end{array}$ & $\begin{array}{l}-0.0007^{*} \\
2.55 \mathrm{E}-05\end{array}$ & $\begin{array}{r}0.0005^{*} \\
7.21 \mathrm{E}-05\end{array}$ & $\begin{array}{l}-0.0007^{*} \\
2.71 \mathrm{E}-05\end{array}$ & $\begin{array}{c}0.0006^{*} \\
8.77 \mathrm{E}-05\end{array}$ \\
\hline Family size & $\begin{array}{c}-0.008^{*} \\
(0.0002)\end{array}$ & $\begin{array}{c}-0.009 * \\
(0.0002)\end{array}$ & $\begin{array}{c}-0.005^{*} \\
(0.0005)\end{array}$ & $\begin{array}{c}-0.009 * \\
(0.0002)\end{array}$ & $\begin{array}{c}-0.006 * \\
(0.0008)\end{array}$ \\
\hline Number of child & $\begin{array}{c}0.031^{*} \\
(0.0005)\end{array}$ & $\begin{array}{c}0.031^{*} \\
(0.0006)\end{array}$ & $\begin{array}{r}0.026 * \\
(0.0008)\end{array}$ & $\begin{array}{r}0.032 * \\
(0.0007)\end{array}$ & $\begin{array}{l}0.017^{*} \\
(0.001)\end{array}$ \\
\hline deflated income & $\begin{array}{c}-4.54 \mathrm{E}-06 * \\
(1.76 \mathrm{E}-07)\end{array}$ & $\begin{array}{c}-4.28 \mathrm{E}-06 * \\
(1.71 \mathrm{E}-07)\end{array}$ & $\begin{array}{l}-6.08 \mathrm{E}-06 * \\
(2.02 \mathrm{E}-07)\end{array}$ & $\begin{array}{c}-4.24 \mathrm{E}-06^{*} \\
(1.78 \mathrm{E}-07)\end{array}$ & $\begin{array}{c}-3.99 \mathrm{E}-06 * \\
(1.94 \mathrm{E}-07)\end{array}$ \\
\hline Years in the U.S & & & $\begin{array}{r}-0.00125^{*} \\
7.39 \mathrm{E}-05\end{array}$ & & $\begin{array}{r}-0.00147^{*} \\
8.13 \mathrm{E}-05\end{array}$ \\
\hline Number & 899706 & 826861 & 121572 & 778131 & 48728 \\
\hline
\end{tabular}


In the naturalized analysis we control for length of stay in the U.S and our base group is White naturalized immigrant. We find that in comparison to White naturalized immigrant, all other races/ethnic groups except mixed race are more likely to use welfare. What is however different in the comparison among the naturalized immigrants versus the native born is the magnitude of the difference. Among naturalized immigrants, the welfare usage gap is much smaller than among the native born. On average naturalized women from other race/ethnic groups are 2-3\% more likely to use welfare than their White naturalized counterparts. In contrast native born women of minority decent are 3-8\% more likely to use welfare than their White native born counterparts. What this finding suggests is that race/ethnicity per se is not what creates this preference but race is proxying for some other experience that may explain this higher preference for welfare usage. We explore this issue of experience more by considering the impact of birth place. We hypothesize that if race is in some way or form proxying for experience then if we look at differences in welfare usage based on birth place we would see even more significant differences among women. Where an individual is born to a large extent affect an individual's view to life given the unique experiences the individual goes through. Table 4 panel A summarizes this analysis. A-priori, if welfare usage is based on need and nothing else, then among comparable women, birthplace should not matter. However given our earlier finding on racial differences among women in welfare usage, then birthplace difference in welfare usage may not be surprising. Column (1) focuses on the whole sample, column (2) on Naturalized immigrants and Column (3) on citizens. We will focus on the results for citizens in column (3) because preference for welfare is revealed among citizens only. Our base group is born in the U.S. Interestingly, we do not see any differences in welfare usage based on birth place among women citizens from every birthplace apart from those born in U.S protectorates. For this group, we find they are 5.8\% more likely to use welfare than women born in the U.S. For all other groups: women born in Africa, Asia, Europe, Oceania , South America, Asia and Central America and the Caribbean, welfare usage is identical to that of women born in the U.S. This result suggest that experience may not matter as much and the question then becomes what is the race variable capturing? In column (4) of Table 4 panel A we redo the same analysis but this time controlling for race. We find that our result persists, birthplace of women does not seem to matter in welfare usage for most women, the exception being women from U.S territories. Controlling for race, leads to a shrinking of this coefficient by over a 50\%. The analysis in Table 4 allows us to re-examine the impact of race when birthplace is controlled for. The result reinforces the earlier result in Table 3 column (2) and suggest 
that controlling for birthplace does not affect the race coefficient significantly for all but one group; Asian. When birthplace was not controlled for our result seemed to suggest that citizen women from Asia used welfare more than White women citizens. However this result is not robust. If we control for birthplace we find that there is no difference between welfare usage for women from these two groups. The lack of significance of birthplace for most regions and the persisting significance of race may lead some to conclude that experience is not important and race is important for welfare usage. However, such a conclusion may be wrong because though birthplace does not matter in general based on how we constructed birthplace, experience may still be important and a breakdown of birthplace into broad categories closely linked to continents as we have done may hide heterogeneous experiences. One way to get at if birthplace really matters or if race really matters is to create an interaction of both dummies. Table 4 panel B captures some of the results of the coefficients for this new dummy variable. What can we potentially get from this interaction analysis? We potentially can get at if race really matters. ${ }^{7}$ If we see that comparable Hispanic women from every birthplace use welfare more than White women born in the U.S and comparable Black women irrespective of birthplace use welfare more than White women born in the U.S then concluding that a race preference for welfare usage exists will be appropriate.

Given this analysis results in creating over 20 dummy variables, we only highlight in Table 4 panel B a select number of the estimates of the interaction dummy coefficient. Our results suggest that race is not really the issue. We find that Black and Hispanic with Birthplaces in Central America and the Caribbean, Blacks and Hispanics with Birthplace in South America, Blacks and Hispanics with birthplaces in Europe and Blacks in Africa, all exhibit similar welfare preferences as White Americans born in the U.S. In contrast, comparable Hispanic and Blacks born in the U.S or in U.S territories and Native Americans all exhibit higher preference for welfare than White women born in the U.S. We displayed in Table 4 panel B a few of our race birthplace interaction dummies. However, all of the interaction dummies apart from those already mentioned turned out to be insignificant. For example, we do not highlight the Black born in Africa and White born in Africa dummy. However, comparable Black women born in Africa and White women born in Africa have similar probability of using welfare as White women born in the U.S.

\footnotetext{
${ }^{7}$ Here we focus on if being a Hispanic or Black women makes you prefer welfare given the Asian women share similar preference as White women and native American Women as a group cannot be found anywhere else but the U.S
} 
Table 4: Does Birthplace really matter for Welfare usage among women

\begin{tabular}{|c|c|c|c|c|c|c|}
\hline & \multicolumn{3}{|c|}{ Panel A } & \multirow[b]{2}{*}{ citizens } & \multicolumn{2}{|l|}{ Panel B } \\
\hline & \multirow[t]{2}{*}{ ALL } & Naturalized & citizens & & \multirow[b]{2}{*}{$\begin{array}{l}\text { (Race/birthplace } \\
\text { dummy) }\end{array}$} & \multirow[b]{2}{*}{ (5) } \\
\hline & & $(2)$ & (3) & (4) & & \\
\hline U.S. & $0.098 * * *$ & & $0.058 * *$ & $0.024 * *$ & Hispanic born & $0.045^{* *}$ \\
\hline protectorate & [0.017] & & {$[0.02]$} & {$[0.014]$} & in the U.S & [0.001] \\
\hline \multirow[t]{2}{*}{ CAC } & 0.048 & $0.039^{\prime *}$ & 0.047 & 0.004 & Black born & $0.09 * *$ \\
\hline & [0.041] & [0.023] & [0.045] & [0.027] & in the U.S & [0.002] \\
\hline South & 0.0316 & 0.008 & 0.026 & -0.004 & Native American & $0.074 * *$ \\
\hline America & [0.037] & [0.0204] & {$[0.038]$} & [0.023] & born in the U.S & [0.005] \\
\hline \multirow[t]{2}{*}{ Europe } & 0.0407 & -0.006 & 0.024 & 0.023 & Asian born & -0.002 \\
\hline & [0.039] & [0.017] & {$[0.037]$} & [0.035] & in the U.S & [0.003] \\
\hline \multirow[t]{2}{*}{ Asia } & $0.062^{*}$ & 0.019 & 0.045 & 0.05 & Whites born & 0.012 \\
\hline & {$[0.045]$} & {$[0.02]$} & [0.044] & {$[0.046]$} & in the U.S territory & [0.019] \\
\hline \multirow[t]{2}{*}{ Africa } & $0.072^{\prime *}$ & 0.024 & 0.024 & 0.0004 & Hispanic born & $0.098^{*}$ \\
\hline & [0.0501] & {$[0.026]$} & {$[0.038]$} & {$[0.026]$} & in the U.S territory & [0.025] \\
\hline \multirow[t]{2}{*}{ Pacific } & 0.052 & & 0.014 & 0.018 & Black born in & $0.054 *$ \\
\hline & {$[0.047]$} & & {$[0.037]$} & [0.038] & U.S territory & [0.029] \\
\hline \multirow[t]{2}{*}{ Others } & 0.062 & 0.005 & 0.019 & 0.001 & Whites born & 0.005 \\
\hline & [0.0471] & [0.021] & {$[0.036]$} & {$[0.026]$} & in CAC & [0.014] \\
\hline Canada & 0.025 & -0.008 & 0.017 & 0.01 & Hispanic born & 0.022 \\
\hline and other NA & {$[0.035]$} & [0.016] & [0.034] & {$[0.031]$} & in $C A C$ & [0.014] \\
\hline \multirow[t]{2}{*}{ Hispanic } & NA & NA & NA & $0.046 * *$ & Black born & 0.013 \\
\hline & & & & {$[0.001]$} & in CAC & [0.014] \\
\hline \multirow[t]{2}{*}{ Black } & NA & NA & NA & $0.088 * *$ & Whites born & -0.006 \\
\hline & & & & [0.002] & in Europe & [0.014] \\
\hline Native & NA & NA & NA & $0.074 * *$ & Hispanic born & 0.007 \\
\hline American & & & & [0.004] & in Europe & [0.012] \\
\hline \multirow[t]{2}{*}{ Asian } & NA & NA & NA & -0.0004 & Black born & -0.004 \\
\hline & & & & [0.002] & in Europe & [0.014] \\
\hline Mixed & NA & NA & NA & $0.034 * *$ & & \\
\hline race & & & & [0.003] & & \\
\hline $\mathrm{N}$ & 899706 & 48717 & 826861 & 826861 & & 823835 \\
\hline
\end{tabular}

Notes: Base group for column (1) is Born in the U.S, for column(2) born in the pacific region, column (3) born in the U.S, for column (4) base groups are born in the U.S for birthplace and White for race/ethnicity. For column (5) base group is White born in the U.S. 


\section{Inference}

In this paper we considered two questions: (i) Does race/ethnicity affect welfare usage among comparable women; (ii) Does past exposure as captured by a woman's birthplace affect the probability of using welfare? Our prior is that if we control for what typically should predict welfare usage, then race or birthplace should not matter. However, if nontraditional factors such as past experience or exposure to different institutions affects preference for welfare, then we may see racial or birthplace differences. We find that race strictly does not affect the probability of comparable women using welfare programs. Instead, the significant race dummy is proxying for something else beyond race, which we hypothesize could be a subgroup's experience but could be some other factor. In addition what this result tells us is that documented differences in welfare usage by race noted in past literature do not suggest a racial or ethnic preference/inclination for welfare usage but usage based on need.

This finding is important given evidence that the urge to pass welfare reform in 1996 was driven in part by a sense that immigrants and minorities had an inclination for welfare use or were the face of welfare. ( see Kellstedt 2003 and Martin Gilens , 2003). Although the issue of race was rarely explicit, in the pre reform debates, Soss and Schram 2006 noted that arguments tended to carry a racial underpinning because so many Americans identified welfare recipients as poor black women or immigrants. We also find that birthplace does not matter for welfare usage. However, our characterization of birthplace by continent and not country in most cases might have reduced the efficacy of the variable to capture exposure given significant heterogeneity within continent. Our finding of only women with birth place in U.S territories as more likely to use welfare may be evidence of the need to look at birthplace at a more disaggregate level. However, what the lack of differential welfare usage based on birthplace tells us is that comparable naturalized female immigrants and citizens share similar probability of welfare usage.

Our analysis is not without limitations. First, we consider any type of welfare usage equally which could be viewed as restrictive. In reality, different welfare programs have different welfare costs and it may be useful to look at them separately. In addition although we control for income, we do not control for wealth which some may argue could affect an individual's probability of welfare participation. We are of the opinion that wage and income are more relevant for predicting welfare usage and wealth is more 
important for other longer term outcomes. Nonetheless, if wealth is relevant, then the women we claim are comparable are really not.

Finally, given our finding of similar inclination for welfare usage for most comparable women, the focus of policy makers should be on how to put in place policies so that women particularly minorities get out of welfare usage. Improving nongovernmental income, education, employment, and health are all potential starting points in an attempt to reduce welfare usage among women.

We hope to focus future research on investigating carefully what the race variable is proxying for, among Black and Hispanic U.S born, in our welfare usage analysis for women. In addition, we hope to consider welfare usage based on birthplace at a more disaggregate level.

\section{References}

Kellstedt, Paul M. 2003. The Mass Media and the Dynamics of American Racial Attitudes. New York, NY: Cambridge University Press.

Gilens, Martin. 1999. Why Americans Hate Welfare: Race, Media, and the Politics of Antipoverty Policy. Chicago: University of Chicago Press.

Blau, Francine (1984). The Use of Transfer Payments by Immigrants. Industrial and Labor Relations Review, 37(2), pp. 222-239.

Bitler Marianne, Gelbach Jonah and Hoynes Hilary (2002). The Impact of welfare reform on Marriage and Divorce. Federal Reserve Bank of Atlanta, working Paper 2002-9

Borjas, George (1994). The Economics of Immigration. Journal of Economic Literature, 32(4), pp. 1667-1717.

Borjas George \& Trejo Stephen J. (1991). Immigrant Participation In TheWelfare System. Industrial and Labor Relations Review, 44(2), pp. 195-211

Borjas, G. J. (1999). Immigration and welfare magnets. Journal of Labor Economics, 17(4), pp. 607-637.

Borjas George \& Lynette Hilton (1996). Immigration and the Welfare State: Immigrant Participation in MeansTested Entitlement Programs. The Quarterly Journal of Economics, 111(2), pp. 575-604.

Carnochan Sarah, Ketch Virginia, De Marco Allison, Taylor Sarah, Abrahamson Anne, Austin J. Michael. Assessing the impact of Welfare reform: A Synthesis of research Studies (1998-2002).

Davis, L. and hagen J. (1996). Stereotypes and Stigma: What's changed for welfare mothers.Affilia, vol 11, pp. 319-337

Greenwell Lisa, Leibowitz Arleen and Klerman Jacob (1998). Welfare Background, Attitudes, and Employment Among New Mothers. Journal of Marriage and the Family, vol. 60, pp. 175-193

Hansen, Jorgen \& Lofstrom, Magnus (2003). Immigrant Assimilation and Welfare Participation: Do Immigrants Assimilate Into or Out of Welfare?. Journal Human Resources XXXVIII (1), pp. 74-98. 
Hunt, M. (1996). The Individual, Society, or both? A comparison of Black, Latino, and White beliefs about the causes of poverty. Social Forces, vol. 75, pp. 293-322

Seccombe Karen, Walters Battle Kimberly and James Delores (1999). “welfare Mothers” Welcome Reform, Urge Compassion. Family Relations, Vol. 48, pp. 197-206

Smith K. B. and Stone L. B. (1989). Rags, Riches, and bootstraps: Beliefs about the causes of . The Sociological Quaterly, vol. 30, pp. 93-107wealth and Poverty

Soss Joe and Schram Sanford (2006). "Coloring the terms of membership: Reinventing the Divided Citizenry in an Era of Neoliberal Paternalism. National Poverty Center, Working paper \#06-13

Oyelere, Ruth and Oyolola Maharouf (2009). Do Immigrants Differ in Welfare Usage? Evidence from the US. IZA Discussion Paper 4659. 